\title{
HELMINTHOSES OF GOATS BREEDING AT BELGRADE AREA
}

\author{
I. Pavlović ${ }^{1}$, S. Ivanović ${ }^{1}$, M. Žujovié́ ${ }^{2}$ Z. Tomić ${ }^{2}$ \\ ${ }^{1}$ Scientific Veterinary Institute of Serbia, Belgrade, Republic of Serbia \\ ${ }^{2}$ Institute for Animal Husbandry, Belgrade-Zemun, Republic of Serbia \\ Corresponding author: dr_ivanp@yahoo.com \\ Original scientific paper
}

Abstract: In aim of control parasitic infection of goat we started to sistematic parasitological examination of it. At Belgrade area we examined flocks of goats originated from 23 vilages from city districts Mladenovac, Lazarevac, Obrenovac, Grocka, Zemun, Surčin, Palilula, Voždovac and Zvezdara. Using standart coprological methods we examined 221 faecal samples. At same time, with necropsy we examined 67 animals. We found the following helminthes species: Dicrocoelium dendriticum (83,25\%), Moniezia expansa $(52,36 \%)$, Echinococcus granulosus (cyst) (83,25\%), Trchostrongylus axei $(79,82 \%)$, T.colubriformis $(69,57 \%), \quad$ T. capricola $(62,85 \%)$, Ostertagia circumcincta (65,23\%), O. ostertagi (23,33\%), Nematodirus spathiger (83,25\%), N. filicolis (43,31\%), Hameonchus contortus (58,95\%), Skrjabinema caprae (13,28\%), Chabertia ovina (44,14\%), Oesophagostomum venulosum $(28,39 \%)$, and Dictyocaulus filaria $(56,45 \%)$

Key words: goats, helminthes, Belgrade

\section{Introduction}

Way of breeding usualy at shepeng had prerequisite to a lot of infections including parasitoses (Quesada et al., 1990; Ashraf and Nepote 1989; Rattray, 2003). Pasture breeding make possible contact within sheep and eggs, larvar stages and intermediate host of parasites (Fake,1990; Barger 1994; Pavlović et al.1995). Those induce that there are no one small ruminants without parasites (Smith,1990; Jovanović et al.1991; Vujić et al.1991). Negative influence of parasitic infection reflected througt lost of weight and decrement quantum of lactation (Mishra,1991; Luginbuhl,1998; Kristmundsson and Richter, 2000).

No study had previously made to determine endoparasites fauna of goats in Serbia. Ever, examination of goats parasitoses were only sporadically performed and we had only afew paper about it (Vujić and Bošković,1981; Ilić,1990; Vujić et al.1991; Ilić et al.1991; Pavlović et al.1995). 
From these reasoni in mind, we started with examination of parasitic fauna of goats at various pats of Serbia. At first, we started at Belgrade area, during 2003, and at our paper we presented results obtained in period 2009-2010.

\section{Materials and Methods}

During our examination we examined flocks of goats originated from 23 vilages from city districts Mladenovac, Lazarevac, Obrenovac, Grocka, Zemun, Surčin, Palilula, Vozdovac and Zvezdara. Using standart coprological methods we examined 221 faecal samples (Pavlović and Anđelić-Buzadžić, 2010b). A total of 21 goats and lambs were examined in the slaughter house at Vojka. After slaughter we collected trachea, lung, heart, complete gastrointestinal tract, liver, kidney and urinary bladder and examined it at laboratory of Scientific Veterinary Institute. The intestine and the other organs were slit opened and visible helminths removed. Intestine contents were washing out and washing were scanned over a sieve, mesh aperture $150 \mu \mathrm{m}$, under jet water and the retained material examined small quantities at a time. Found parasites either fixing in $10 \%$ formalin,were mounted in lactofenol for identification, and mounted in Canada balsam. The determination was done by keys given by Dunn (1978).

\section{Results and Discussion}

During examination we recorded 1 trematoda species, 2 cestoda species (one adult and one cystic form) and 12 species of nematode. Poliparasitismus and infection with gastointestinal helmints were established at all examined animals. Numerous parasites were found at small intestine, followed by abomasus and at colon.

We found the following helminthes species: Dicrocoelium dendriticum (83,25\%), Moniezia expansa (52,36\%), Echinococcus granulosus (cyst) $(83,25 \%)$, Trchostrongylus axei $(79,82 \%)$, T. colubriformis $(69,57 \%)$, T. capricola $(62,85 \%)$, Ostertagia circumcincta $(65,23 \%)$, O. ostertagi (23,33\%), Nematodirus spathiger (83,25\%), N. filicolis (43,31\%), Hameonchus contortus (58,95\%), Skrjabinema caprae (13,28\%), Chabertia ovina (44,14\%), Oesophagostomum venulosum (28,39\%), and Dictyocaulus filaria $(56,45 \%)$

Most prevalence species of nematode are Trichostrongylus and Ostertagia species. Although most of the gastro-intestinal species appear to follow this general pattern of seasonal distribution, some variations in intensively and duration of these characteristics with different worm species occurred. Thus with Trichostrongylus and Ostertagia species infection at mature goats the spring peak was more pronounced that the autumn infection (Pavlović, 2009c,d; Pavlović et al., 2009b; 2010a,b). Prevalence of Moniezia expansa, Dicrocoelium dendriticum and Dictyocaulus filaria were simillar at other aprt of Serbia where we examined parasites of small ruminants (Pavlović et al., 2003, 2008, 2010a). 
Generally speaking the goat's parasites represent a global problem. The countries of Magreb (Morocco, Tunisia and Algeria), Middle East and Africa are in permanent battle with parasitic infections and losses ensued by them (Quesada et al., 1990, Fakae, 1990, Wamae and Ihiga, 1990). Same situation are at Mediterranean basin where especially problem present Echinococcosis/Hydatidosis which occurred on goats and sheep at rate of 70-90\% (Pavlović and Ivanović, 2006; Pavlović et al, 2011a). Goat helnthoses had a worldwide distribution. We had a reports from Island (Kristmundsson and Richter, 2000) to NewZeland (Rattray, 2003), from Pakistan (Bilqees, 1988) and India (Mishra, 1991), to USA (Ashraf and Nepote, 1990).

The data on harmful before and effect of parasitic infections on the goat performance undoubtedly show that in the anthelminth conditions of rearing high performance animals it is necessary to conduct the measures of prophylactic treatment (Barger et al., 1994; Zajac and Gipson, 2000; Chartier et al., 2000; Kaplan et al. 2004; Shaik et al. 2004; Pavlović et al., 2009a).

\title{
Conclusion
}

However, since the parasitic infections are in majority sub clinical. The attention has not been paid to this problem in Serbia. The prophylactic treatment is not conducted in the majority of flocks or it is only partially performed what can be seen by the records from the slaughter line and from production results. In aim of introducing parasites fauna of goats and prepare measure to its control we must to continue our examination. This would be the only way to obtain better product results, characteristics and quality of goats and lambs meat in ecological breeding condition

\section{Acknowledgment}

Research was financed by the Ministry of Education and Science, Republic of Serbia, project TR 31053.

\section{Helmintoze koza sa područja Beograda}

\author{
I. Pavlović, S. Ivanović, M. Žujović, Z. Tomić
}

\section{Rezime}

U cilju kontrole parazitskih infekcija koza potrebno je utvrditi vrste i distribuciju parazita. U radu dajemo prikaz helminata koza sa područja Beograda. Istraživanja su vršena u 23 sela na području opština Mladenovac, Lazarevac, 
Obrenovac, Grocka, Zemun, Surčin, Palilula, Voždovac i Zvezdara. Primenom standardnih koproloških metoda pregledan je 221 uzorak izmeta. Isto tako, ispitali za obdukciju 67 životinja. Ustanovljene su sledeće vrste helminata: Dicrocoelium dendriticum (83,25\%), Moniezia expansa (52,36\%), Echinococcus granulosus (cyst) (83,25\%), Trchostrongylus axei (79,82\%), T. colubriformis $(69,57 \%), T$. capricola (62,85\%), Ostertagia circumcincta $(65,23 \%)$, O. ostertagi $(23,33 \%)$, Nematodirus spathiger $(83,25 \%)$, N. filicolis $(43,31 \%)$, Hameonchus contortus (58,95\%), Skrjabinema caprae (13,28\%), Chabertia ovina (44,14\%), Oesophagostomum venulosum $(28,39 \%)$, i Dictyocaulus filaria $(56,45 \%)$

\section{References}

ASHRAF M., NEPOTE K.H. (1989): Prevalence of gastrointestinal nematodes, coccidian and lungworm in Maryland dairy goats. Small Rumin.Res., 3, 291-298.

BARGER I.A.,SIALE K., BANKS D.J.D., LE JAMBRE L.F. (1994): Rotational grazing for control of gastrointestinal nematodes of goats in a wet tropical environment. Vet. Parasitol., 53, 109-116.

BILQEES F.M. (1988) Parasites of sheep and goats in Karchi with special reference to hydatidosis and fasciolosis. Proceed.Parasitol., 50-58.

CHARTIER C., ETTER E., HESTE H., PORS I., KOCH C., DELLAC B. (2000): Efficacy of copper oxide needles for the control of nematode parasites in dairy goats. Vet. Res. Commun., 24, 389-399.

DUNN A. (1978): Veterinary Helminthology. William Heinemann Medical Book, London 172-195 p.

FAKAE, B.B. (1990): The epidemiology of helminthosis iin small ruminants under the traditional husbandry system in estern Nigeria. Vet.Res.Comm., 5, 381-391.

JOVANOVIĆ D., ILIĆ G., NEŠIĆ D., PAVLOVIĆ I., VALTER D. (1991): Parasites fauna of sheep at Timok District in period 1986-1989. Proceeding of I Internationaln Summer Conference for Advancement of Sheep and Goat Production, Ohrid, 10-15.9.1991., 383-385;

ILIĆ G. (1990): Parasitic fauna of goats and pathological changes at goat at Timok District. PhD disertation, Faculty of Veterinary Medicine, University in Belgrade. ILIĆ G., JOVANOVIĆ D., NEŠIĆ D., PAVLOVIĆ I. (1991): Parasitose in goat and its role in pathology of goat at Timok District in period 1986-1989. Proceeding of I International Summer Conference for Advancement of Sheep and Goat Production, Ohrid, 390-395.

KAPLAN R.J., BURKE T., TERRILL J., MILLER W., GETZ S., MOBINI V. (2004): Validation of the FAMACHA $\odot$ eye color chart for detecting clinical anemia in sheep and goats on farms in the southern United States. Veterinary Parasitology, 123, 105-120. 
KRISTMUNDSSON Á., RICHTER S.H. (2000): Lung- and gastrointestinal helminthes of goats (Capra hircus) in Iceland. Icel.Agr. Sci. 13, 79-85.

LUGINBUHL J.M. (1998): Gastrointestinal Parasite Management of Meat Goats. North Carolina State University.

MISHRA K.C. (1991): Study on same aspects of health and performance of Sikkim local goats, International Journal of Animal science 6, 104-110.

PAVLOVIĆ I., KULIŠIĆ Z. , NEŠIĆ D., ROMANIĆ S. (1995): Endoparasites of sheep and goats in Prizren district Proceeding of 3rd International Conference of Sheep and Goats Production, Ohrid, Macedonia, 106-110.

PAVLOVIC I., IVANOVIC S., ZUJOVIC M. (2003): Moniezioza ovaca na području Dimitrovgrada. Zbomik referata simpozijuma V epizootioloski dani sa medunarodnim ucecem, Subotica, 140-142.

PAVLOVIC I., IVANOVIĆ S. (2006): Ehinokokoza/hidatidoza,bolest životinja i ljudi, izd. Naučni institut za veterinarstvo Srbije i Ministarstvo poljoprivrede, šumarstva i vodoprivrede, Beograd, 1-32

PAVLOVIĆ I., KULIŠIĆ Z., SAVIĆ B., STANKOVIĆ B. (2008): Dikrocelioza ovaca i koza na području Beograda, Zbornik radova i kratkih sadržaja X simpozijum epizootiološki dani sa međunarodnim učešćem, 239-241.

PAVLOVIĆ I., SAVIĆ B., IVETIĆ V., RADANOVIĆ O., ŽUTIĆ M., JAKIĆDIMIĆ D., BOJKOVSKI J. (2009a): The effect of parasitic infections to production results of sheep Proceeding of IV Balkan Conference of Animal Science BALNIMALCON 2009, Challanges of the Balkan Animal industry and the Role of science and Cooperation, 14-16.5.2009. Stara Zagora, Bulgaria, 389-391.

PAVLOVIĆ I., IVETIĆ V., SAVIĆ B., RADANOVIĆ O., ŽUTIĆ M., IVANOVIĆ S. (2009b) Želudačno-crevna strongilidoza koza i ovaca na području Beograda Zbornik naučnih radova Instituta PKB Agroekonomik, 15, 3-4,123-127.

PAVLOVIĆ I. (2009c): Endoparaziti koza i ovaca: helmintoze. Veterinarski informator, 33,70.

PAVLOVIĆ I. (2009d): Endoparaziti koza i ovaca: Plućna i želudačno-crevna strongilidoza. Veterinarski informator, 34-35, 55.

PAVLOVIĆ I., IVANOVIĆ S., ŽUJOVIĆ M., TOMIĆ Z. (2010a): Plućna strongilidoza koza Zbornik naučnih radova Instituta PKB Agroekonomik, 16, 3-4, 171-177.

PAVLOVIĆ I., ANĐELIĆ-BUZADŽIĆ G. (2010b): Osnovi dijagnostike parazitskih bolesti životinja za studente visoke poljoprivredne škole strukovnih studija U Šapcu studijski program: strukovna veterina Naučni institut za veterinarstvo Srbije, 1-28.

PAVLOVIĆ I., HADŽIĆ I., ŽUGIĆ G., ANĐELIĆ-BUZANIĆ G., VAIĆ D., JOVČEVSKI S. (2011a): Hidatidoza aktuelni problem stočarske proizvodnje Zbornik naučnih radova Instituta PKB Agroekonomik, 17, 3-4, 133-139. 
PAVLOVIĆ I., IVANOVIĆ S., ŽUJOVIĆ M., TOMIĆ Z., MEMIŠI N. (2011b): Fascioloza koza u Srbiji Zbornik naučnih radova Instituta PKB Agroekonomik, 17, 3-4,163-169.

QUESADA A., CRINGOLI G., BOCHICCHIO V., MINNMAN P. (1990): Research on helminths of sheep and goats in Basilicata. note I: Aetioepidemiological investigations. Acta Med. Vet., 36, 10, 41-59.

RATTRAY P.V. (2003): Helminth parasites in the New Zealand Meat \& wool pastoral industries: A Review of Current Issues, Final Report by Commissioned By Meat \& Wool Innovation Ltd.

SHAIK S., TERRILL J. MILLER B. KAUAKOU G. KANNAN R. KALLU T. (2004): Effects of feeding sericea lespedeza hay to goats infected with Haemonchus contortus. South Afr. J. Anim. Sci., 34, 248-250.

SMITH M.C. (1990): Exclusion of infectious diseases from sheep and goat farms. Vet. Clinic. North America, Food Anim.Prac., 6, 705-720.

VUJIĆ B., BOŠKOVIĆ V (1981): Health monitoring of goats and possibility to promote of goats production. Vet.Glas., 7, 739-743.

VUJIĆ B., BOŠKOVIĆ V., SAVIN Ž. (1991): Most important parasites species of sheep and goat and its eradication. Proceeding of I International Summer Conference for Advancement of Sheep and Goat Production, 375-381.

WAMAE L.W., IHIGA M.A.K. (1990) Seasonal faecal egg count changes in Kenyan goats through one year period. Bull. Anim. Healt. Product. Africa, 38, 1-4. ZAJAC A., GIPSON T. (2000): Multiple anthelmintic resistances in goat herd. Vet. Parasitol., 87, 163-172.

ZURIILSKI P., RUSEV I. (1990): Prevalence of gastrointestinal nematodes among goats in Bulgaria. Vet.Sbirka, 88, 45-46. 